\title{
QUEEN'S
QNEIVERSITY
BELFAST
}

\section{Revolutionaries for the Right: anticommunist internationalism and paramilitary warfare in the Cold War.}

Gerth, M. (2019). Revolutionaries for the Right: anticommunist internationalism and paramilitary warfare in the Cold War. Cold War History, 19(2), 317-320. https://doi.org/10.1080/14682745.2019.1601412

\author{
Published in: \\ Cold War History
}

\section{Document Version:}

Peer reviewed version

Queen's University Belfast - Research Portal:

Link to publication record in Queen's University Belfast Research Portal

\section{Publisher rights}

Copyright 2019 T \& F. This work is made available online in accordance with the publisher's policies. Please refer to any applicable terms of use of the publisher.

\section{General rights}

Copyright for the publications made accessible via the Queen's University Belfast Research Portal is retained by the author(s) and / or other copyright owners and it is a condition of accessing these publications that users recognise and abide by the legal requirements associated with these rights.

Take down policy

The Research Portal is Queen's institutional repository that provides access to Queen's research output. Every effort has been made to ensure that content in the Research Portal does not infringe any person's rights, or applicable UK laws. If you discover content in the Research Portal that you believe breaches copyright or violates any law, please contact openaccess@qub.ac.uk. 
Gerth, Matthew. Review of Revolutionaries for the Right: Anticommunist Internationalism and Paramilitary Warfare in the Cold War, by Kyle Burke. Cold War History, vol. 19 no. 2 (May 2019): 317-320.

In this new addition to the ever growing body of Cold War literature, Kyle Burke attempts to shed light upon the efforts of the vast array of right-wing armed movements and their American backers in waging an attempted global war against communism from the 1950s until the 1980s. This book seeks to underscore the significant contribution by private citizens of the United States in this 'anti-communist crusade'. It details accounts from both the boardroom and the battlefield of conservative Americans seeking and striving to create an independent foreign policy - in the efforts to aid right-wing regimes and anti-communist guerrilla insurgents - regardless of the stated doctrines and policies of their own national government.

Revolutionaries for the Right takes the reader to exotic war-torn jungles and highlights the exploits of anti-communist armies and paramilitaries in the field; however, the main setting is not the front line, but locations that are often seen as more banal and pedestrian. Burke focuses on the lecture circuits, fundraising drives, press junkets, and countless conferences which proved instrumental in raising funds and procuring would-be mercenaries from within the United States. If one is seeking a detailed account of anticommunist military operations during the Cold War this book is ill-suited for the task. It is as much a tale about the American conservative movement seeking to find a role in the wider world in the last part of the twentieth century as it is an account of anti-communists fighting throughout the Global South. In this endeavour Burke succeeds by both crafting a readable narrative and tracing the attempts of individual Americans and their international allies in forging an effective 'anti-communist international'.

The underlying current throughout the Cold War that drove conservative Americans in autonomously supporting the creation of an anti-communist international was rooted in the belief that the United States government held neither the will nor the resolve, nor sanctioned effective methods in fighting 'Soviet imperialism' on the world stage. These right-wingers pointed to a litany of perceived failures by the American government in confronting communist expansion. This protracted list included: not halting the fall of China; the refusal to intervene militarily during the Hungarian Revolution; the Bay of Pigs debacle, specifically the refusal to give the Cuban exiles air support; the State Department's non-recognition of the pro-West Congolese region of Katanga as an independent nation; economic and military sanctions on Rhodesia and South Africa; the botched handling of the Vietnam conflict; and the limitations placed on the Reagan administration by congress in aiding right-wing rebels in Angola and Nicaragua. Increasingly - with each new disappointment or betrayal - the notion held by members of the New Right was that the United States had abandoned the fight against communism.

The strategy promoted by these armchair policymakers and weekend warriors for ameliorating these missteps by the American government involved a mixture of romanticised populism and free-market rhetoric. They presumed the solution to winning the Cold War was simple. By promoting citizen armies funded by the private sector (yet also supporting ostracised right-wing authoritarian regimes such as Augusto Pinochet's Chile and Apartheid 
South Africa) the fight against international communism could be transformed into a winnable one. By the 1980s American conservatives were 'convinced that the U.S. government, especially liberals in congress, had forsaken the anti-communst struggle [and] they concluded foreign paramilitaries were the ideal proxy warriors who could conquer the Marxist threat once and for all' (119). Free from the cumbersome bureaucracy and concerns over human rights which accompanies liberal democracies, this approach for rolling back Soviet influence rested on an ethos American conservatives had sought to implement in their own country, namely the virtue of rugged individualism sustained by the entrepreneurial spirit.

Burke implements a chronological approach to the narrative that he unfolds in Revolutionaries for the Right. Beginning in the early 1950s, shortly after the Chinese Communist Revolution, he zeros in on the efforts of the conservative organiser and later-life gay rights activist, Marvin Liebman, who is one of the two main protagonists that the author focuses upon in this monograph - the other being the retired US army general John Singlaub, the central figure in the later chapters of the book. The author describes how Liebman, alongside prominent members of the conservative movement, such as William F. Buckley, sought early in the Cold War to procure funding for armed anti-communist movements in various parts of the world. Tapping into the fears of wealthy businessmen and large corporations, these initial efforts to create a unified anti-communist international had little success. Liebman did achieve the establishment of numerous private organisations which lobbied the American government and funded specific international movements and activities of the anti-communist persuasion. However, none of these came close to a unified and consolidated front that US conservatives thought necessary to defeat the worldwide 'Red Menace'. Not until the creation of the World Anti-Communist League (WACL) in 1967, which brought activists and organisations from across Asia, Africa, Latin America, and Eastern Europe together, did the dream of an anti-communist international appear to these Americans as achievable. Yet when confronted by the methods and tactics which the nonAmerican members of the newly founded umbrella organisation employed, they balked, leading to a retreat of their influence and contribution into the WACL. Filling this void were more extremist and reactionary elements. As Burke describes:

It took less than a decade for most Americans to sour on the WACL and its affiliates. The group was too radical and too uncontrollable, they said. Moreover, the Americans' vision of the anticommunist international - centered on propaganda campaigns, training academies, and conference - clashed with the violent actions of their overseas allies. Talking about wars of national liberation was one thing. Making them was another. (55-6)

Burke details in the middle part of the book the creation of Operation Condor by state intelligence agencies of the Southern Core as well as the efforts of Rhodesia to recruit American volunteers into both the Rhodesian Army and police force. He maintains that during the mid-to-late 1970s, after the United States' defeat in Vietnam, the prevailing perception of many rightists was that South American dictators and white-controlled governments of South Africa and Rhodesia had taken the lead in the fight against communism from the shell-shocked Americans. This section covers much scholarly ground that previous researchers have already examined in great detail. The original contributions in this part have less to do with the actions of reactionary South Americans and racist states in Africa than with investigating the seeds of private US citizenry involvement in the coming 
covert wars of the 1980s - namely Afghanistan, Nicaragua, and El Salvador - which comes to fruition in the final chapters of Revolutionaries for the Right.

Although the book is relatively free of major factual errors, one of note is when the author describes the infamous Georgian congressman Larry McDonald as a Republican (82) when in fact McDonald remained a life-long Democrat: some of themes and conclusions do not fit into the narrative that Burke has attempted to forge.

One motif that crops up numerous times within the book is the trope of martial masculinity as a baser motive for American conservatives to financially support or physically join anti-communist movements in foreign lands. One example of the usage of this type of language is: 'Although these men were among the wealthiest and most powerful figures in the growing conservative movement in the United States, they felt impotent on the world stage' (57). Little tangible evidence is provided here to bolster this claim, other than some glowing physical descriptions in Solider of Fortune magazine of Jonas Savimbi, a leading anti-communist guerrilla fighter in Angola, and Rhodesian recruitment propaganda that promised American recruits the potential to meet single women if they chose to immigrate to Rhodesia. In fact, Burke describes how a female former army officer and confederate of Singlaub, Karen McKay, played a major role in supporting the anti-Soviet Afghan resistance. He also reports how a Texan millionairess gave quite generously to Liebman's various anticommunist organisations. Allusions to marital status, machismo, and fears of effeminacy are dotted throughout the text; however, this perceived motivation is never touched upon in the conclusion and reads hollow, like an attempted thematic scheme that simply petered out due to lack of empirical data.

In the conclusion Burke endeavours to link conservative Americans' attempts to create an anti-communist international during the Cold War with domestic terrorism and the constitutional militia movement of the 1990s. Here again the evidence he provides is scant and subjective. Burke labours to make a connection with Waco, Ruby Ridge, and the Oklahoma City bombing to the cause of anti-communist guerrilla paramilitaries. This attempt falls short, since no direct links between supporters or participants of the covert wars of the 1980s were involved with any of these events. Nor does the book display any research that the domestic militia movement had anything more than a quasi-spiritual connection with the past attempts to forge an anti-communist international.

Taken as a whole, Revolutionaries for the Right is, pardon the pun, a revolutionary addition to both the historiography of Cold War anti-communism and the American conservative movement. It is well researched and draws from a wealth of archival and secondary sources. The book works as a perfect companion piece to the recently published collection of essays edited by Luc Van Dongen, Stéphanie Roulin, and Giles Scott-Smith entitled Transnational Anti-communism and the Cold War (Basingstoke: Palgrave Macmillian, 2014). Scholars searching for a readable narrative to grasp the phenomenon of the Right's reaction to communism during the Cold War should look no further than this book by Kyle Burke. 